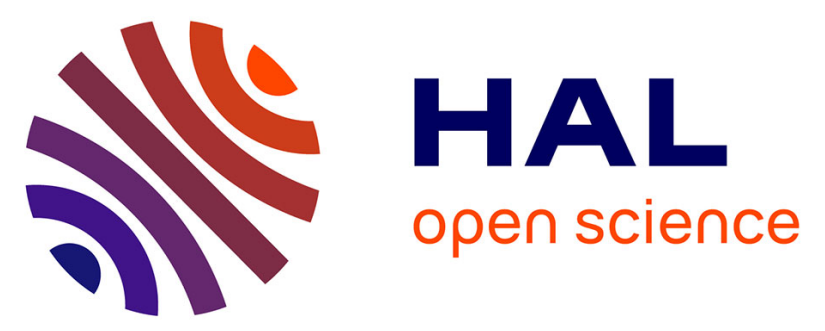

\title{
Mechanical signals modulated vascular endothelial growth factor-A (VEGF-A) alternative splicing in osteoblastic cells through actin polymerisation.
}

Céline Faure, Marie-Thérèse Linossier, Luc Malaval, Marie-Hélène

Lafage-Proust, Sylvie Peyroche, Laurence Vico, Alain Guignandon

\section{To cite this version:}

Céline Faure, Marie-Thérèse Linossier, Luc Malaval, Marie-Hélène Lafage-Proust, Sylvie Peyroche, et al.. Mechanical signals modulated vascular endothelial growth factor-A (VEGF-A) alternative splicing in osteoblastic cells through actin polymerisation.. BONE, 2008, epub ahead of print. 10.1016/j.bone.2008.02.011 . ujm-00270279

\section{HAL Id: ujm-00270279}

\section{https://hal-ujm.archives-ouvertes.fr/ujm-00270279}

Submitted on 4 Apr 2008

HAL is a multi-disciplinary open access archive for the deposit and dissemination of scientific research documents, whether they are published or not. The documents may come from teaching and research institutions in France or abroad, or from public or private research centers.
L'archive ouverte pluridisciplinaire HAL, est destinée au dépôt et à la diffusion de documents scientifiques de niveau recherche, publiés ou non, émanant des établissements d'enseignement et de recherche français ou étrangers, des laboratoires publics ou privés. 
Title

Authors

Affiliations

Running title

Keywords

Corresponding

author
Mechanical signals modulated Vascular Endothelial Growth Factor-A (VEGF-A) alternative splicing in osteoblastic cells through actin polymerization

Céline FAURE, Marie-Thérèse LINOSSIER, Luc MALAVAL, MarieHélène LAFAGE-PROUST, Sylvie PEYROCHE, Laurence VICO, Alain GUIGNANDON ${ }^{\#}$

INSERM U890, St-Etienne, F-42023, France, Laboratoire de Biologie du Tissu Osseux, IFR143-IFRESIS, Université Jean Monnet, StEtienne, F-42023 France.

\# Corresponding author

Mechanical stretch modulates VEGF alternative splicing

Mechanical stretch frequency; Osteoblasts; VEGF; F-actin; Alternative splicing

Alain Guignandon, PhD

INSERM U890, Laboratoire de Biologie du Tissu Osseux, IFR143

15 rue Ambroise Paré, F-42023 St Etienne cedex 2,

Phone: 33-477421445, Fax: 33-477575572

Email: Alain.Guignandon@univ-st-etienne.fr

Number of Words 7673 - 52540 characters with spaces - 21 pages

Figures and $\quad 6$ [all black and white]

Tables

1

None of the authors has any conflicts of interest. 


\section{Abstract}

Since VEGF-A is involved in mechanically-induced bone gain and because vegf exists under 6 isoforms exerting various biological effects, we studied vegf isoforms expression and VEGF protein production in osteoblastic cells (rat Ros17/2.8 and human osteoblasts) submitted to 4 mechanical regimens. Mechanical regimens ( $1 \%$ stretch deformation) were designed with a fixed number of cycles (450) delivered at various frequencies $(0.05$ to $5 \mathrm{~Hz})$. We found a negative correlation $\left(R^{2}=0.76, p<0.0001\right)$ between production of soluble VEGF and mechanical stretch frequency and a positive correlation $\left(R^{2}=0.99\right.$, $p<0.0001$ ) between production of matrix-bound VEGF and mechanical stretch frequency. mRNA expressions of soluble VEGF isoforms $(121,165)$ were specifically expressed under Iow frequency while matrix-bound VEGF isoforms $(206,189,165,145)$ were specifically expressed under high frequency in human osteoblasts. As F-actin stress fibers formation was significantly increased selectively in high frequencies conditions, we disrupted actin fibers in Ros17/2.8 and found that immobilisation of VEGF was abolished. Conversely, jasplakinolide treatment which increases stress fibers formation was able to mimic high frequency stretch-induced immobilisation of VEGF. Thus, we speculate that the stretchinduced increase in cell tension is responsible for matrix-bound vegf isoform production. Mechanically-induced selection of soluble or matrix-bound VEGF production may modify osteoblast and endothelial cells crosstalk crucial during osteogenesis and fracture healing. 


\section{Introduction}

Mechanical strain plays a critical role in bone formation $(46)((29,50)$ by stimulating osteoblastic activities (29) (24) but also by inducing the production of pro-angiogenic factors such as vascular endothelial growth factor A (VEGF) (57). VEGF in cooperation with the fibroblast growth factor (FGF) family, insulin growth factor-1 (IGF-1), epidermal growth factor (EGF), platelet-derived growth factor-A (PDGF-A), and the transforming growth factor-ß (TGF-ß) family, are all involved in bone angiogenesis (19) (40) (16) (25) (12). In a previous work, we demonstrated the absolute necessity of VEGF signaling for bone gain under mechanical strain as mechanically-induced bone gain was fully prevented by a treatment with neutralizing VEGF antibodies (60). Alternative splicing of primary transcript from a single VEGF pre-mRNA produces at least five different isoforms of which three (VEGF-121, 165 and 189) are more prevalent in human (15) (56) (61). VEGF-121 is totally released in the supernatant whereas $70 \%$ of VEGF 165 can remain trapped into the matrix (26) according to matrix amount. VEGF-145, 189 and 206 are completely sequestered into the matrix (26) (41). VEGF isoforms have different biological activities. For example in epiphyseal cartilage, Maes et al. (37) showed that the longer VEGF isoforms produced by hypertrophic chondrocytes and sequestered in the cartilage matrix will be release by proteases and act upon endothelial cells, chondroclasts/osteoclasts, and osteoblasts, thereby coupling metaphyseal vascularization, cartilage resorption, and bone formation. When the epiphyseal cartilage exceeds a critical size during development, the midst of the growth plate becomes hypoxic, triggering VEGF expression in immature chondrocytes. Soluble VEGF isoforms are critical to diffuse to the perichondrium and stimulate outgrowth of the epiphyseal vascular network and subsequent vascular invasion preceding secondary ossification. The murine VEGF188 (human VEGF189) isoform is insufficient for these functions, due to restricted diffusion capacities.

Along with chondrocytes and endothelial cells, osteoblast lineage has to be considered as an important source of VEGF (57) and vegf is a well known mechanosensitive gene (55). The transcriptional upregulation of VEGF has been shown to be mediated by the binding of hypoxia-inducible factor-1 (HIF-1) to the hypoxia-response element in the 5'-flank region (17). Under several conditions, HIF-1 escapes from the degradation process and is transported to the nucleus to transactivate the VEGF gene.

At the molecular level, both VEGF and mechanical signals are known to regulate common elements such as polymerisation of actin and FAK and PI3K activation (1) (45) (11). Cytoskeleton integrity is a prerequisite to mechanosensitivity (5) (49) and thus drugs able to modulate f-actin polymerisation can be used to manipulate osteoblast mechanosensitivity. 
In this context, we hypothesise that quantitative and qualitative production of VEGF by osteoblasts could be modified as a function of mechanical regimens modalities. To address this question, we designed four mechanical regimens delivering the same energy but varying the frequency of application. We applied 450 cycles of stretch at frequencies ranging from 0.05 to $5 \mathrm{~Hz}$, with relaxation times varying respectively from 0.1 to $20 \mathrm{~s}$ between stretch episodes. We analyzed VEGF isoforms expression and release and we quantified actin stress fibers number as predictor of cellular tension. We used LatrunculinA and Jasplakinolide treatment to manipulate this tension with the perspective to identify a potential link between cellular tension and VEGF isoforms expression.

We found that mRNA expressions of soluble VEGF isoforms $(121,165)$ were specifically expressed under low frequency while matrix-bound VEGF isoforms $(189,165,145)$ were specifically expressed under high frequency. Disruption of actin fibers abolished entrapment of VEGF into matrix. Jasplakinolide treatment which increases stress fibers formation was able to mimic high frequency stretch-induced immobilisation of VEGF. Thus, we speculate that the stretch-induced increase in cell tension is responsible for matrix-bound vegf isoform production. 


\section{Materials and Methods}

\section{Biological material}

- Cell Line: Osteoblastic rat osteosarcoma cells, ROS17/2.8 (American Type Culture Collection, Rockville, MD) were maintained in T75-flask, in alpha modified Eagle's medium (aMEM) supplemented with $10 \%$ fetal calf serum (FCS) (ATGC Biotechnologie, Marne la Vallée, France), $2 \mathrm{mM} \mathrm{L-Glutamine,} \mathrm{and} \mathrm{antibiotics}(50 \mathrm{U} / \mathrm{ml}$ penicillin and $50 \mu \mathrm{g} / \mathrm{ml}$ streptomycin) in a humidified atmosphere of $5 \% \mathrm{CO}_{2}$ at $37^{\circ} \mathrm{C}$

- Primary cells: Human osteoblasts were extracted from children explants (tibia and calcaneum) and collected in sterile conditions at a surgical unit. Briefly, after removing soft tissues, bones chips were reduced to 5-mm-thick fragments. Samples were submitted to a 20 -min enzymatic digestion with $1 \mathrm{mg} / \mathrm{ml}$ collagenase with $10 \%$ trypsin at room temperature. Then the supernatant was collected and in aMEM medium and collagenase was neutralized with medium supplemented with $15 \%$ fetal calf serum (FCS). After a centrifugation, Human primary cells were resuspended with culture medium and maintained in T75-flask, in Dubelcco's modified Eagle's medium (DMEM-Ham F12) supplemented with $10 \%$ fetal calf serum (FCS) (ATGC Biotechnologie, Marne la Vallée, France), $2 \mathrm{mM} \mathrm{L}$-Glutamine, antibiotics (50 U/ml penicillin and $50 \mu \mathrm{g} / \mathrm{ml}$ streptomycin) and $10 \%$ ultroser G (Pall BioSepra, Cergy St Christophe, France) in a humidified atmosphere of $5 \% \mathrm{CO}_{2}$ at $37^{\circ} \mathrm{C}$

\section{Cultures conditions}

After reaching a subconfluent state, Ros17/2.8 or primary osteoblasts were trypsinized with $1 \times$ trypsin-EDTA and plated, at $5 \times 10^{4}$ cells $/ \mathrm{cm}^{2}$, onto flexible, type I collagen-coated silicon-bottomed 6-well Bioflex ${ }^{\circledR}$ plates (Dunn Labortechnik, Germany) and grown with $2 \mathrm{ml}$ of medium per well for $24 \mathrm{hrs}$.

$12 \mathrm{hrs}$ after the end of mechanical treatments, culture medium were collected and stored at $-20^{\circ} \mathrm{C}$. For protein content determination, $300 \mu \mathrm{l}$ of lysis buffer containing $0.5 \%$ Nonidet $40,1 \%$ PIC (proteases inhibition cocktail, Sigma, St Quentin fallavier, France) were used. For VEGF determination by ELISA, supernatants were collected or cell monolayers were lysed with $0.1 \%$ triton-x100 in PBS. Supernatants and lysates were stored at $-20^{\circ} \mathrm{C}$. Before use, lysates were centrifuged ( $5 \mathrm{~min}, 5000 \mathrm{rpm}, 4^{\circ} \mathrm{C}$ ) and supernatants were collected.

\section{Mechanical stretching}

Starting 24 hours after seeding cells were subjected to mechanical deformation induced with a Flexcell Strain Unit Fx-3000 (Flexcell Corp., Hillsborough, NC, US) (3), which consists in a vacuum manifold regulated by solenoid valves controlled by a computer 
timer program. Each plate is inserted over six flat-topped plastic buttons in the Bioflex ${ }^{\circledR}$ loading station. Application, through an air pump, of a negative pressure of 80 kilopascals stretches horizontally the bottom of the culture plate over the plastic button. Thus, 85 percent of the flexible well surface is submitted to a known rate of isometric elongation (maximum $1 \%$ ). The membranes are then released to their original size. As stretched cells remained adherent in these experiments, the deformation of the membrane was directly transmitted to cells. Unstretched cells grown on Bioflex plates were used as controls. All cultures prior and subsequent to the Flexcell regimen were maintained in a humidified atmosphere of $95 \%$ air and $5 \% \mathrm{CO}_{2}$ at $37^{\circ} \mathrm{C}$.

Several regimens were used in this study (Figure 1). Osteoblasts were stretched to $1 \%$ deformation at different frequencies (square signal) from $0.05 \mathrm{~Hz}$ to $5 \mathrm{~Hz}$ during 450 cycles. Each mechanical regimen delivered identical total quantity of mechanical energy. Consequently, duration of strain application varied from 1.5 to 150 minutes in order to accommodate a range of relaxation times (from $0.1 \mathrm{~s}$ to $19.9 \mathrm{~s}$ ) between two deformations. We defined relaxed modes for low frequencies $(0.05$ to $0.25 \mathrm{~Hz})$ and pulsed modes for high frequencies $(2.5$ to $5 \mathrm{~Hz}$ ).

Twelve hours after the end of the strain, cells from stretched and unstretched control (C) cultures were either harvested and extracted to quantify mRNA expression by RT-PCR, or collected along with supernatants for ELISA assay.

In all graphs, values are expressed as percent of controls "C" (100\%) after normalisation by cyclophilin for RT-PCR and total protein amounts for ELISA.

\section{RNA extraction and $R T$}

Total RNA was isolated from the cultured cells $12 \mathrm{~h}$ after treatments using the kit RNeasy Mini Kit (Qiagen, Inc., Valencia, CA). Complementary DNA (cDNA) was synthesized from $2 \mu \mathrm{g}$ of total RNA with the $1^{\text {st }}$ strand CDNA synthesis Kit for RT-PCR (AMV, Roche, Hague Road, Indianapolis). $8 \mu$ l of CDNA mixture diluted 1:20 in water were subjected to realtime PCR using SYBR Green I dye (Lightcycler faststart DNA master SYBR green I, Roche,Penzberg, Germany). Reactions were performed in $20 \mu \mathrm{l} \mathrm{PCR}$ mixture containing $4 \mu \mathrm{l} 5 \mathrm{x}$ Master Mix (dNTP mixture with dUTP instead of dTTP, MgCl2, SYBR Green I dye, Taq DNA Polymerase and reaction buffer), $2 \mu \mathrm{l}$ of $10 \mu \mathrm{M}$ primers (sense and anti-sense: localisation found Fig. 1) and sequences and sources indicated in Table 1 and $6 \mu$ PCR grade water. In rats, uncertain determination of sequences in exon $6 a$ and 7 implied that rat vegf $188+164$ or vegf $144+188$ were detected together. Only vegf120 (exclusively soluble) and 188 (exclusively matrix-bound) can be detected by appropriate sets of primers (Table 1). PCR was performed in a Light Cycler 3.0 Instrument. A typical protocol included a denaturation step at $95^{\circ} \mathrm{C}$ for 480 s followed by 40 cycles at $95^{\circ} \mathrm{C}$ for 
$15 \mathrm{~s}, \mathrm{Tm}^{\circ} \mathrm{C}$ annealing for $10 \mathrm{~s}$ and $72^{\circ} \mathrm{C}$ for extension for $20 \mathrm{~s}$. Gene expression levels were normalized using cyclophilin reference and control corresponded to $100 \%$.

\section{Determination of total protein content}

Protein concentration was determined by spectrophotometry using the bicinchoninic acid (BCA) protein assay kit (Interchim, Pierce). $25 \mu \mathrm{l}$ of sample were mixed with $200 \mu \mathrm{l}$ of working buffer for $30 \mathrm{~min}$ at $37^{\circ} \mathrm{C}$. The absorbency was read with a spectrophotometer (940 KONTRON) at $562 \mathrm{~nm}$ using a blank reference and protein concentration determined from the calibration curve.

\section{VEGF-A sandwich ELISA}

Sandwich Elisa was designed to analyze amount of VEGF-A in culture medium and cell lysates. ELISA assays were performed using the duoset VEGF ELISA kit (R\&D Systems, Minneapolis, MN) according to the manufacturer's instructions. General cross-reactivity for all VEGF isoforms is specified in the ELISA description of the manufacturer. Assays were performed in triplicate, and the readings were compared to standard curves obtained with human recombinant VEGF-A, provided with the kit.

\section{Modulation of actin polymerisation}

We used two modulators of stress fibers formation; jasplakinolide and latrunculin $A$ known respectively to induce or inhibit actin polymerisation, (54) ; (53) ; (4) ; (21). Drugs were added in the medium at $0.1 \mu \mathrm{M}$ for 1 hour and cells were washed with fresh medium prior to mechanical stimulation.

\section{Quantification of actin fiber spacing}

Ros $17 / 2.8$ cells seeded on the collagen-coated silicon membrane were analyzed by fluorescence microscopy and quantitative immunomorphology for determining actin stress fibers number. $12 \mathrm{~h}$ after mechanical strain culture medium was removed. Cells were rinsed with phosphate buffered saline (PBS) and fixed in $4 \%$ paraformaldehyde for $10 \mathrm{~min}$ at room temperature. Samples were washed with PBS and permeabilized with $0.1 \%$ triton- $\times 100$ buffer for $3 \mathrm{~min}$ then washed with PBS. A rhodamine-phalloidin (Interchim, Monluçon, France) stock solution (1:50 dilution) was prepared in a $10 \%$ FCS solution in PBS and cells were incubated for $45 \mathrm{~min}$ at $37^{\circ} \mathrm{C}$. By means of fluorescence microscopy (DMRB, Leica, Bensheim, Germany) f-actin was imaged by a 40 objective at a resolution of $650 \times 515$ pixels.

Image processing was achieved via an autocorrelation algorithm. The autocorrelation of an image volume is computed in order to find average repetitive structures within the 
image (39); (47), such as aligned stress fibers. We used the freely available program ImageJ (http://rsb.info.nih.gov/ij/index.html) implemented with the 2D fast Fourier transformation and autocorrelation plug-ins (http://rsb.info.nih.gov/ij/plugins/acf.html). 30 cells per conditions were evaluated. Selections of $128 \times 128$ pixels were used for autocorrelation calculation, allowing cell by cell fiber detection (Fig. 4). Representative images of fast Fourier transformation are inserted in Figure $4 C$ and $4 D$. The profile plot of the autocorrelation image generated a typical autocorrelation curve. The distance between the two first maximum indicates the typical spacing between the fibrils. As the spacing increased the fibrous pattern became undetectable.

\section{Preservation of matrix-bound VEGF}

In order to remove osteoblastic cells without removing matrix and entrapped VEGF, we applied 3 successive cycles of freezing/defrosting $\left(-80^{\circ} \mathrm{C} / 37^{\circ} \mathrm{C}\right)$ on cellularized membrane. PBS was used as washing buffer in each step.

\section{VEGF localisation after stretches}

Matrices were washed with PBS and fixed in $4 \%$ paraformaldehyde for $10 \mathrm{~min}$ at room temperature. After rinsing in PBS, samples were incubated for $60 \mathrm{~min}$ at $37^{\circ} \mathrm{C}$ with mouse primary antibodies directed against human VEGF (Chemicon UK, MAB3734) diluted $1 / 50$ in PBS with $10 \%$ FCS. Samples were rinsed with PBS and incubated for 60 $\min$ at $37^{\circ} \mathrm{C}$ with goat anti-mouse alexa-fluor-488, diluted $1 / 200$. A Hoescht solution ( $1: 100$ dilution) was prepared in a $10 \%$ FCS solution in PBS and cells were incubated for $5 \mathrm{~min}$ at room temperature. Cells were examined using a fluorescence equipped microscope (DMRB, Leica, Bensheim, Germany) and imaged by a 20 objective at a resolution of $650 \times 515$ pixels.

\section{Statistical analysis}

Statistical analysis was performed with the STATISTICA6 software (StatSoft Inc., Tulsa, OK, USA). All data were analyzed by one-way analysis of variance (ANOVA). When $F$ values for a given variable were found to be significant, comparisons among individual samples were assessed by the post hoc method of Scheffe. Results were considered to be significantly different at $p<0.05$. Pearson correlation analysis was performed to determine relationship between frequency of mechanical regimens and VEGF expression or production. All data are presented as means \pm SD. 


\section{Results}

\section{Low and high frequencies had opposite effect on release or immobilisation of VEGF}

We compared, in Ros17/2.8, our 4 regimens in their ability to increase mRNA expressions of Hif $1 \alpha, 6$ hours post-stretch, (Fig. 2A) and VEGF-A, 12 hours post-stretch (Fig. 2B). Surprisingly, we observed that all mechanical strains increased significantly Hif1 $\alpha$ expression (about 1.5 folds compare to control). We found comparable results for total VEGF-A ( 1.4 to 1.6 fold increased as compared to control). In order to confirm the results obtained on VEGF-A gene, we quantified VEGF proteins amount by ELISA. ELISA of VEGF protein was performed on supernatants of Ros17/2.8 cultures to quantify soluble VEGF proteins and in cell/matrix lysates to quantify matrix-bound VEGF. The two lowest frequencies (largest relaxation time: relaxed mode) increased soluble VEGF protein, assayed on the supernatant ( 1.5 and 1.2 fold at $0.05 \mathrm{~Hz}$ and $0.25 \mathrm{~Hz}$, respectively) (Fig. 2C). The highest frequency regimen, $5 \mathrm{~Hz}$ (shortest relaxation time = pulsed mode), decreased soluble VEGF protein amounts while the $2.5 \mathrm{~Hz}$ regimen had no significant effect on soluble VEGF release. The release of soluble VEGF was thus negatively correlated to mechanical frequency $\left(R^{2}=0.76, p<0.0001\right)$. In contrast, matrix-bound VEGF amounts increased in a frequency-dependant manner (Fig. 2D), while $0.05 \mathrm{~Hz}$ frequency regimen did no differ significantly from $\mathrm{C}, 0.25 \mathrm{~Hz}, 2.5 \mathrm{~Hz}$ and $5 \mathrm{~Hz}$ regimens increased insoluble VEGF $1.1,1.4$ and 1.6 fold respectively. A high positive correlation was found between non soluble VEGF and mechanical stretch frequency $\left(R^{2}=0.99\right.$, $p<0.0001$ ). These results could be explained by a selective expression of VEGF isoforms.

\section{Difference between soluble and non-soluble VEGF production reflected differential isoform expression}

In order to test the hypothesis that VEGF alternative spicing is modulated by mechanical stretch frequency we performed Real time-PCR on Ros17/2.8 of soluble and matrixbound vegf isoforms respectively vegf120 and vegf188 (Fig. 3A) We found a specific upregulation of vegf120 isoform under low frequency stretch and a specific upregulation of vegf188 under high frequency stretch. In order to confirm the results obtained on sarcoma cells, we performed, RT-PCR on primary human osteoblasts, $12 \mathrm{~h}$ post-stretch (relaxed mode versus pulsed mode) following specifically the 5 major human vegf isoforms. We found that soluble isoform 121 was significantly upregulated ( 1.7 fold $)$ under relaxed mode and that matrix-bound isoforms 206, 189 and 145 were upregulated (2.5, 2.4 and 2.3 fold respectively) under pulsed mode. We found also that isoform 165 was significantly upregulated under both modes (Fig. 3B). These results were confirmed by VEGF protein expression. We found a significant release of VEGF under $0.05 \mathrm{~Hz}$ in 
primary human osteoblasts and not for $5 \mathrm{~Hz}$ stretch (Fig. 3C) and a significant increase in cell-matrix immobilisation of VEGF under $5 \mathrm{~Hz}$ not found for $0.05 \mathrm{~Hz}$ stretch (Fig. 3D). These results are in accordance with results obtained in Ros17/2.8. That release of VEGF in the supernatant was not increased under pulsed mode indicated that human VEGF165 was immobilized under high stretching frequency. The use of human osteoblast allowed us to appraise $\mathrm{HiF} 1 \alpha$ protein stability $12 \mathrm{~h}$ post-stretch. We found that HIFl $\alpha$ production was still elevated ( 3 fold increase; Fig. 3E) in human cell submitted to $0.05 \mathrm{~Hz}$ stretch and modestly but significantly elevated in $5 \mathrm{~Hz}$ stretch condition suggesting $\mathrm{HIF}$ dependent upregulation of VEGF under our conditions of stretch. To address the question of VEGF localization, relaxed or pulsed membranes were submitted to cycles of freezing/unfrezzing to carefully remove cells. After that membranes were processed for immunoassaying of VEGF and Hoechst staining to attest for the absence of cells. In these conditions we found that VEGF was only detectable in the pulsed stretch condition $(5 \mathrm{~Hz}$;

Fig. 3F). This experiment strongly suggested that immobilization of VEGF was into matrix.

\section{Activation of stress fibers formation was correlated with production of matrix- bound VEGF}

In Fig. 4A (C, $0.05 \mathrm{~Hz}$ and $0.25 \mathrm{~Hz}$ frequency regimens, respectively) only few actin fibers were observed in Ros17/2.8 under stretch and the spacing was high, not different from controls. In Fig. 4D and E (2.5 and 5Hz frequency) well developed fibers were observed and fiber spacing was low. Autocorrelations analysis (Fig. 4F) indicated significantly difference in fiber spacing for pulsed regimens (frequency: 2.5 and $5 \mathrm{~Hz}$ ) as compared to control, demonstrating that only pulsed modes were able to induce or maintain actin polymerisation $12 \mathrm{~h}$ post-stretch. As pulsed modes had a stabilising effect on the cytoskeleton, we tested whether these results could be mimicked using drugs targeting the actin cytoskeleton.

\section{I ncrease in cellular tension was necessary for matrix trapping of VEGF}

As expected a large number of stress fibers were formed (Fig. 5A) (comparable to $5 \mathrm{~Hz}$ regimen results, Fig. $\mathbf{4 A} \mathbf{5 H z}$ ) when Ros17/2.8 cells were treated with Jasplakinolide. Latrunculin A treatment (Fig. 5A) led to the loss of central stress fibers. We first observed that Jasplakinolide upregulate vegf188 isoform expression (Fig. 5B) and had no effect on vegf120 isoform (Fig.5C). Concomitantly, we observed that Jasplakinolide increased significantly insoluble VEGF protein amount ( 1.5 fold) but had no effect on soluble VEGF protein amount (Fig. 5D). Surprisingly LatrunculinA (Fig. 5E) had no effect on matrix-bound nor soluble VEGF protein secretion despite the significant decrease observed for the vegf188 isoform expression (Fig. 5B). These results led us to the 
conclusion that cellular architecture was a mediator of matrix-bound VEGF production but did not regulate the release of VEGF under stretch. In order to demonstrate that mechanically induced-stress fibers formation was responsible for immobilisation of VEGF into the matrix, we pre-treated cells with LatrunculinA before relaxed or pulsed mechanical stimulation. $12 \mathrm{~h}$ post-stretch at $0.05 \mathrm{~Hz}$, actin was significantly depolymerised (Fig. 6A), similar to cells treated with LatrunculinA (Fig. 5A). In contrast, $12 \mathrm{~h}$ poststretch at $5 \mathrm{~Hz}$ (Fig. 6A), actin polymerisation returned to control levels although stress fibers were not detectable. Interestingly, despite the fact that actin polymerisation was still impaired after $0.05 \mathrm{~Hz}+$ LatA mechanically induced release of VEGF was not abolished ( 1.5 fold increase vs C) confirming that cell tension was not involved in stretch-induced VEGF secretion (Fig. 6C). $12 \mathrm{~h}$ post-stretch at $5 \mathrm{~Hz}$, we did not find any increase in the amount of VEGF in cell/matrix lysates (Fig. 6D). Absence of VEGF immobilisation under $5 \mathrm{~Hz}$ stretch was supported by the specific abolition of the vegf188 upregulation found in $5 \mathrm{~Hz}$ stretched cells, furthermore the release of VEGF found under relaxed stretch $(0.05 \mathrm{~Hz})$ is supported by the specific upregulation of vegf120 isoform despite the Lat.A treatment (Fig. 6B). All together these results indicated that actin polymerisation (i.e. increased cell tension) was necessary for VEGF immobilisation and not for VEGF release. 


\section{Discussion}

In this study, we show that mechanical strain differentially regulates production of VEGFA isoforms by osteoblasts (rat sarcoma cells and human primary cells), according to the frequency of the applied signal. Moreover, we show that mechanical information delivered in a pulsed mode leads to actin polymerisation which induces matrix-bound VEGF production.

Our guideline for the choice of the mechanical stimulation regimens was to apply the same total amount of energy, but delivered at increasing frequencies in order to reduce cell-relaxation time. We provide evidence that a short time of relaxation between loads does not impair ROS $17 / 2.8$ cells and primary human osteoblast mechanosensitivity. These results were in accordance with those of Rubin (20) and Klein-Nulend groups (2). We fixed the signal amplitude at $1 \%$ stretch, as we previously demonstrated that osteoblasts were sensitive to this degree of deformation in the Flexercell-3000 system (7). A longer time of mechanical stimulation delivered in pulsed mode detached cells and a shorter time in relaxed mode failed to upregulate Hif-1a or VEGF expressions (data not shown).

In vivo mechanical information is delivered to bone cells through various types of stimuli (i.e.: compression, tension, fluid-flow piezoelectric currents) all characterized by various amplitudes and frequencies of application. In rat tibiae, when resting periods are inserted between loading bouts, periosteal bone formation is enhanced as compared to an uninterrupted loading regimen, suggesting the existence of a refractory period in the mechanotransduction signalling cascade of bone cells (44). Indeed, in vitro studies demonstrated that bone cells present a refractory period to fluid flow-induced calcium waves (13) and to electrical field (9). These results lead to the conclusion that periods of recovery between two periods of mechanical stimulations are necessary for osteoblasts to restore their complete mechanosensitivity (8). However, recent studies from CT Rubin's group (32) suggest that bone cell activities could benefit from high frequencies of stimulation (20-90 Hz), if their amplitudes are very low. Thus, osteoblast mechanosensitivity is not clearly defined in terms of refractory period as relaxation time between loading bouts may vary from milliseconds to hours depending on the system studied. The ultimate source of confusion is that the total mechanical energy delivered to cells is not kept constant (the increase in frequency being not compensated by a reduction in duration of application). 
In osteoblasts, Hif1 alpha has been shown to transactivate target genes such as Vegf (57) and mechanical strain was already shown to induce both Hif1 alpha and Vegf expression in other cell types (23) (38) (43) (34). In this study, Hif1 alpha is systematically upregulated at the mRNA level by all mechanical regimens applied to osteoblastic cells, despite their different design and Hif1 alpha is still present at the protein level 12 hours post-stretch. Hif1 alpha upregulation might explain why VEGF expression is stimulated. Interestingly, Hif1 alpha and subsequently VEGF induction were shown to occur in the nonhypoxic myocardium under mechanical stress (34). In our cell culture under standard conditions (i.e., $20 \% \mathrm{O}_{2}$ ), cells were not hypoxemic and it is plausible that VEGF induction might result from non hypoxic Hif1 alpha. Under non hypoxic conditions, NO donors (33) have been described to increase Hif1 alpha expression. As NO is known as a key regulator in mechanotransduction (36), we can speculate that in our mechanical stretch conditions, Hif1 alpha is maintained elevated via NO upregulation.

Mechanically-induced upregulation of VEGF has been already described in several cell types (42) (52) including osteoblasts (55) (51) and for a wide range of mechanical stimulation. The correlation we found between VEGF secretion and mechanical frequencies is explained by a selective expression of VEGF isoforms. To our knowledge, only one study (42) reported frequency-dependent VEGF isoform expression. These authors showed that tendon fibroblasts produce VEGF 121 and 165 when stimulated at $1 \mathrm{~Hz}$ but not at $0.5 \mathrm{~Hz}$. It has been shown that the vegf gene has two start codons (AUG and CUG) (27) (6) which are responsible for the different isoforms production. We hypothesize that the relaxed mode strain activates the CUG start codon, inducing vegf 121, while the pulsed mode strain shifts expression to the AUG start codon, leading to the production of vegf 189. This might also explain the production of vegf 165 under both modes, as this splice variant is produced equivalently by CUG and AUG start codons.

Both VEGF and mechanical stimuli regulate stress fibers formation (28) (22). We found that $12 \mathrm{~h}$ post-stretch, pulsed mode strain induces a sustained actin polymerisation, as quantified by image analysis. The relaxed mode failed to maintain stress fibers, demonstrating that this process is frequency-dependent. The modulator of cell tension, jasplakinolide, binds to pointed ends of actin filaments (F-actin) thereby stabilizing the binding interface between adjacent actin monomers (G-actin) (10) (18) (35) which inhibits filament depolymerisation (58) and favors nucleation and polymerisation. We show that Jasplakinolide-induced stress fibers result in an increase of non soluble VEGF protein amounts, with no effect on soluble VEGF production. Jasplakinolide is thus acting 
as a mechano-mimetic. Cells treated with latrunculin $A$ which disrupts microfilament organisation without obvious effects on the organization of the microtubular system, do not display any VEGF production. However, when cells pretreated with latrunculin A are submitted to a relaxed mechanical regimen, soluble VEGF is produced. Importantly, no stimulation of non soluble VEGF was detected under pulsed regimen. We thus conclude that active $\mathrm{f}$-actin polymerisation is required for matrix-bound VEGF production under mechanical stress. It has been reported that PI3K activity, an important modulator of actin polymerisation (31), is required for VEGF expression (14). Other works show that latrunculin A decreases PTEN, the natural inhibitor of PI3K (30). The maintenance of PI3K activity and the intense peripheral $\mathrm{f}$-actin polymerisation may explain why soluble VEGF is produced in latrunculin A treated cells under relaxed mode strain.

Thus, if cell contraction is impaired, as in latrunculin A treated cells, matrix-bound VEGF cannot be produced. Since Jasplakinolide treatment was able to mimic pulsed induced osteoblast response we conclude that cell contractility, and not only $f$-actin polymerisation, is essential for the storage of VEGF into matrix. We hypothesize that RhoGTPase, especially the RhoA/ROCK pathway, (48) (59) controls this process.

In conclusion, we show that mechanical stretch regulates, in a frequency dependent manner, the expression of VEGF variants by osteoblasts, and thus the integration of this crucial messenger molecule into the matrix. This study increases our knowledge on the role of VEGF as an osteogenic/angiogenic factor and might offer new potential by which critical angiogenic factors can be release in a spatio-temporally mechanical controlled manner to help vascularization of cellularized bone scaffolds or bone repair.

\section{Acknowledgements}

This study was supported by European Space Agency: European Research In Space and Terrestrial Osteoporosis (ERISTO) contract number 14232/00/NL/SH; Microgravity Application Programme AO-99-122 and by the Institut National de la Santé et de la Recherche Médicale. 


\section{References}

[1]. Abedi, H., and Zachary, I. Vascular endothelial growth factor stimulates tyrosine phosphorylation and recruitment to new focal adhesions of focal adhesion kinase and paxillin in endothelial cells. J Biol Chem. 1997; 272: 15442-51.

[2]. Bacabac, R. G., Smit, T. H., Van Loon, J. J., Doulabi, B. Z., Helder, M., and KleinNulend, J. Bone cell responses to high-frequency vibration stress: does the nucleus oscillate within the cytoplasm? Faseb J.2006; 20:858-64.

[3]. Banes, A. J., Gilbert, J., Taylor, D., and Monbureau, O. A new vacuum-operated stress-providing instrument that applies static or variable duration cyclic tension or compression to cells in vitro. J Cell Sci.1985; 75:35-42.

[4]. Beningo, K. A., Dembo, M., Kaverina, I., Small, J. V., and Wang, Y. L. Nascent focal adhesions are responsible for the generation of strong propulsive forces in migrating fibroblasts. J Cell Biol.2001; 153:881-8.

[5]. Bershadsky, A. D., Ballestrem, C., Carramusa, L., Zilberman, Y., Gilquin, B., Khochbin, S., Alexandrova, A. Y., Verkhovsky, A. B., Shemesh, T., and Kozlov, M. $M$. Assembly and mechanosensory function of focal adhesions: experiments and models. Eur J Cell Biol.2006; 85: 165-73.

[6]. Bornes, S., Boulard, M., Hieblot, C., Zanibellato, C., Iacovoni, J. S., Prats, H., and Touriol, C. Control of the vascular endothelial growth factor internal ribosome entry site (IRES) activity and translation initiation by alternatively spliced coding sequences. J Biol Chem.2004; 279:18717-26.

[7]. Boutahar, N., Guignandon, A., Vico, L., and Lafage-Proust, M. H. Mechanical strain on osteoblasts activates autophosphorylation of focal adhesion kinase and prolinerich tyrosine kinase 2 tyrosine sites involved in ERK activation. J Biol Chem.2004; 279: 30588-99.

[8]. Brand, R. A., and Stanford, C. M. How connective tissues temporally process mechanical stimuli. Med Hypotheses.1994; 42: 99-104.

[9]. Brighton, C. T., Okereke, E., Pollack, S. R., and Clark, C. C. In vitro bone-cell response to a capacitively coupled electrical field. The role of field strength, pulse pattern, and duty cycle. Clin Orthop Relat Res.1992; 255-62.

[10]. Bubb, M. R., Senderowicz, A. M., Sausville, E. A., Duncan, K. L., and Korn, E. D. Jasplakinolide, a cytotoxic natural product, induces actin polymerization and competitively inhibits the binding of phalloidin to F-actin. J Biol Chem.1994; 269: 14869-71.

[11]. Cezar-de-Mello, P. F., Nascimento-Silva, V., Villela, C. G., and Fierro, I. M. Aspirin-triggered Lipoxin A4 inhibition of VEGF-induced endothelial cell migration involves actin polymerization and focal adhesion assembly. Oncogene.2006; 25: $122-9$.

[12]. Dickson, K. M., Bergeron, J. J., Philip, A., O'Connor-McCourt, M., and Warshawsky, H. Localization of specific binding sites for 125I-TGF-betal to fenestrated endothelium in bone and anastomosing capillary networks in enamel organ suggests a role for TGF-betal in angiogenesis. Calcif Tissue Int.2001; 68:304-15.

[13]. Donahue, S. W., Donahue, H. J., and Jacobs, C. R. Osteoblastic cells have refractory periods for fluid-flow-induced intracellular calcium oscillations for short bouts of flow and display multiple low-magnitude oscillations during long-term flow. J Biomech.2003; 36:35-43.

[14]. Fang, J., Ding, M., Yang, L., Liu, L. Z., and Jiang, B. H. PI3K/PTEN/AKT signaling regulates prostate tumor angiogenesis. Cell Signal.2007; 19:2487-97.

[15]. Ferrara, N., Houck, K., Jakeman, L., and Leung, D. W. Molecular and biological properties of the vascular endothelial growth factor family of proteins. Endocr Rev.1992; 13: 18-32.

[16]. Fiorelli, G., Orlando, C., Benvenuti, S., Franceschelli, F., Bianchi, S., Pioli, P., Tanini, A., Serio, M., Bartucci, F., and Brandi, M. L. Characterization, regulation, 
and function of specific cell membrane receptors for insulin-like growth factor I on bone endothelial cells. J Bone Miner Res.1994; 9:329-37.

[17]. Forsythe, J. A., Jiang, B. H., Iyer, N. V., Agani, F., Leung, S. W., Koos, R. D., and Semenza, G. L. Activation of vascular endothelial growth factor gene transcription by hypoxia-inducible factor 1. Mol Cell Biol.1996; 16:4604-13.

[18]. Gallo, G., Yee, H. F., Jr., and Letourneau, P. C. Actin turnover is required to prevent axon retraction driven by endogenous actomyosin contractility. J Cell Biol.2002; 158: 1219-28.

[19]. Garcia-Ramirez, M., Toran, N., Andaluz, P., Carrascosa, A., and Audi, L. Vascular endothelial growth factor is expressed in human fetal growth cartilage. J Bone Miner Res.2000; 15:534-40.

[20]. Garman, R., Rubin, C., and Judex, S. Small oscillatory accelerations, independent of matrix deformations, increase osteoblast activity and enhance bone morphology. PLoS ONE.2007; 2: e653.

[21]. Goeckeler, Z. M., and Wysolmerski, R. B. Myosin light chain kinase-regulated endothelial cell contraction: the relationship between isometric tension, actin polymerization, and myosin phosphorylation. J Cell Biol.1995; 130:613-27.

[22]. Guignandon, A., Usson, Y., Laroche, N., Lafage-Proust, M. H., Sabido, O., Alexandre, C., and Vico, L. Effects of intermittent or continuous gravitational stresses on cell-matrix adhesion: quantitative analysis of focal contacts in osteoblastic ROS 17/2.8 cells. Exp Cell Res.1997; 236:66-75.

[23]. Hasaneen, N. A., Zucker, S., Lin, R. Z., Vaday, G. G., Panettieri, R. A., and Foda, $H$. D. Angiogenesis is induced by airway smooth muscle strain. Am J Physiol Lung Cell Mol Physiol.2007; 293:L1059-68.

[24]. Hoberg, M., Gratz, H. H., Noll, M., and Jones, D. B. Mechanosensitivity of human osteosarcoma cells and phospholipase $\mathrm{C}$ beta2 expression. Biochem Biophys Res Commun.2005; 333:142-9.

[25]. Horner, A., Bord, S., Kemp, P., Grainger, D., and Compston, J. E. Distribution of platelet-derived growth factor (PDGF) A chain mRNA, protein, and PDGF-alpha receptor in rapidly forming human bone. Bone.1996; 19:353-62.

[26]. Houck, K. A., Leung, D. W., Rowland, A. M., Winer, J., and Ferrara, N. Dual regulation of vascular endothelial growth factor bioavailability by genetic and proteolytic mechanisms. J Biol Chem.1992; 267:26031-7.

[27]. Huez, I., Bornes, S., Bresson, D., Creancier, L., and Prats, H. New vascular endothelial growth factor isoform generated by internal ribosome entry site-driven CUG translation initiation. Mol Endocrinol.2001; 15:2197-210.

[28]. Hutchings, H., Ortega, N., and Plouet, J. Extracellular matrix-bound vascular endothelial growth factor promotes endothelial cell adhesion, migration, and survival through integrin ligation. Faseb J.2003; 17:1520-2.

[29]. Jaasma, M. J., Jackson, W. M., Tang, R. Y., and Keaveny, T. M. Adaptation of cellular mechanical behavior to mechanical loading for osteoblastic cells. J Biomech. 2007; 40: 1938-45.

[30]. Janetopoulos, C., Ma, L., Devreotes, P. N., and Iglesias, P. A. Chemoattractantinduced phosphatidylinositol 3,4,5-trisphosphate accumulation is spatially amplified and adapts, independent of the actin cytoskeleton. Proc Natl Acad Sci U S A.2004; 101:8951-6.

[31]. Jimenez, C., Portela, R. A., Mellado, M., Rodriguez-Frade, J. M., Collard, J., Serrano, A., Martinez, A. C., Avila, J., and Carrera, A. C. Role of the PI3K regulatory subunit in the control of actin organization and cell migration. J Cell Biol.2000; 151:249-62.

[32]. Judex, S., Lei, X., Han, D., and Rubin, C. Low-magnitude mechanical signals that stimulate bone formation in the ovariectomized rat are dependent on the applied frequency but not on the strain magnitude. J Biomech.2007; 40:1333-9.

[33]. Kasuno, K., Takabuchi, S., Fukuda, K., Kizaka-Kondoh, S., Yodoi, J., Adachi, T., Semenza, G. L., and Hirota, K. Nitric oxide induces hypoxia-inducible factor 1 activation that is dependent on MAPK and phosphatidylinositol 3-kinase signaling. J Biol Chem.2004; 279:2550-8. 
[34]. Kim, C. H., Cho, Y. S., Chun, Y. S., Park, J. W., and Kim, M. S. Early expression of myocardial HIF-1alpha in response to mechanical stresses: regulation by stretchactivated channels and the phosphatidylinositol 3-kinase signaling pathway. Circ Res.2002; 90: E25-33.

[35]. Lee, E., Shelden, E. A., and Knecht, D. A. Formation of F-actin aggregates in cells treated with actin stabilizing drugs. Cell Motil Cytoskeleton.1998; 39: 122-33.

[36]. Liedert, A., Kaspar, D., Blakytny, R., Claes, L., and Ignatius, A. Signal transduction pathways involved in mechanotransduction in bone cells. Biochem Biophys Res Commun.2006; 349: 1-5.

[37]. Maes, C., Stockmans, I., Moermans, K., Van Looveren, R., Smets, N., Carmeliet, P., Bouillon, R., and Carmeliet, G. Soluble VEGF isoforms are essential for establishing epiphyseal vascularization and regulating chondrocyte development and survival. J Clin Invest.2004; 113:188-99.

[38]. Milkiewicz, M., Doyle, J. L., Fudalewski, T., Ispanovic, E., Aghasi, M., and Haas, T. L. HIF-1 \{alpha\} and HIF-2 \{alpha\} play a central role in stretch-induced but not shear-stress-induced angiogenesis in rat skeletal muscle. J Physiol.2007; 583: 753-66.

[39]. Napadow, V. J., Chen, Q., Mai, V., So, P. T., and Gilbert, R. J. Quantitative analysis of three-dimensional-resolved fiber architecture in heterogeneous skeletal muscle tissue using nmr and optical imaging methods. Biophys J.2001; 80:296875.

[40]. Ornitz, D. M., and Marie, P. J. FGF signaling pathways in endochondral and intramembranous bone development and human genetic disease. Genes Dev.2002; 16: 1446-65.

[41]. Park, J. E., Keller, G. A., and Ferrara, N. The vascular endothelial growth factor (VEGF) isoforms: differential deposition into the subepithelial extracellular matrix and bioactivity of extracellular matrix-bound VEGF. Mol Biol Cell.1993; 4:1317-26.

[42]. Petersen, W., Varoga, D., Zantop, T., Hassenpflug, J., Mentlein, R., and Pufe, T. Cyclic strain influences the expression of the vascular endothelial growth factor (VEGF) and the hypoxia inducible factor 1 alpha (HIF-1alpha) in tendon fibroblasts. J Orthop Res.2004; 22:847-53.

[43]. Pufe, T., Lemke, A., Kurz, B., Petersen, W., Tillmann, B., Grodzinsky, A. J., and Mentlein, R. Mechanical overload induces VEGF in cartilage discs via hypoxiainducible factor. Am J Pathol.2004; 164:185-92.

[44]. Robling, A. G., Burr, D. B., and Turner, C. H. Partitioning a daily mechanical stimulus into discrete loading bouts improves the osteogenic response to loading. J Bone Miner Res.2000; 15: 1596-602.

[45]. Rousseau, S., Houle, F., Kotanides, H., Witte, L., Waltenberger, J., Landry, J., and Huot, J. Vascular endothelial growth factor (VEGF)-driven actin-based motility is mediated by VEGFR2 and requires concerted activation of stress-activated protein kinase 2 (SAPK2/p38) and geldanamycin-sensitive phosphorylation of focal adhesion kinase. J Biol Chem.2000; 275: 10661-72.

[46]. Rubin, C., Turner, A. S., Bain, S., Mallinckrodt, C., and McLeod, K. Anabolism. Low mechanical signals strengthen long bones. Nature.2001; 412:603-4.

[47]. Russell, L. The importance of wound documentation and classification. $\mathrm{Br} J$ Nurs. 1999; 8:1342-3, 46, 48 passim.

[48]. Sarasa-Renedo, A., Tunc-Civelek, V., and Chiquet, M. Role of RhoA/ROCKdependent actin contractility in the induction of tenascin- $C$ by cyclic tensile strain. Exp Cell Res.2006; 312:1361-70.

[49]. Sato, K., Adachi, T., Matsuo, M., and Tomita, Y. Quantitative evaluation of threshold fiber strain that induces reorganization of cytoskeletal actin fiber structure in osteoblastic cells. J Biomech.2005; 38:1895-901.

[50]. Schriefer, J. L., Warden, S. J., Saxon, L. K., Robling, A. G., and Turner, C. H. Cellular accommodation and the response of bone to mechanical loading. J Biomech.2005; 38: 1838-45.

[51]. Singh, S. P., Chang, E. I., Gossain, A. K., Mehara, B. J., Galiano, R. D., Jensen, J., Longaker, M. T., Gurtner, G. C., and Saadeh, P. B. Cyclic mechanical strain 
increases production of regulators of bone healing in cultured murine osteoblasts. J Am Coll Surg.2007; 204:426-34.

[52]. Smith, J. D., Davies, N., Willis, A. I., Sumpio, B. E., and Zilla, P. Cyclic stretch induces the expression of vascular endothelial growth factor in vascular smooth muscle cells. Endothelium.2001; 8:41-8.

[53]. Spector, I., Braet, F., Shochet, N. R., and Bubb, M. R. New anti-actin drugs in the study of the organization and function of the actin cytoskeleton. Microsc Res Tech.1999; 47:18-37.

[54]. Spector, I., Shochet, N. R., Kashman, Y., and Groweiss, A. Latrunculins: novel marine toxins that disrupt microfilament organization in cultured cells. Science.1983; 219: 493-5.

[55]. Thi, M. M., Iacobas, D. A., Iacobas, S., and Spray, D. C. Fluid Shear Stress Upregulates Vascular Endothelial Growth Factor Gene Expression in Osteoblasts. Ann N Y Acad Sci.2007;

[56]. Tober, K. L., Cannon, R. E., Spalding, J. W., Oberyszyn, T. M., Parrett, M. L., Rackoff, A. I., Oberyszyn, A. S., Tennant, R. W., and Robertson, F. M. Comparative expression of novel vascular endothelial growth factor/vascular permeability factor transcripts in skin, papillomas, and carcinomas of $\mathrm{v}$-Ha-ras Tg.AC transgenic mice and FVB/N mice. Biochem Biophys Res Commun.1998; 247:644-53.

[57]. Wang, Y., Wan, C., Deng, L., Liu, X., Cao, X., Gilbert, S. R., Bouxsein, M. L., Faugere, M. C., Guldberg, R. E., Gerstenfeld, L. C., Haase, V. H., Johnson, R. S., Schipani, E., and Clemens, T. L. The hypoxia-inducible factor alpha pathway couples angiogenesis to osteogenesis during skeletal development. J Clin Invest.2007; 117:1616-26.

[58]. Watanabe, N., and Mitchison, T. J. Single-molecule speckle analysis of actin filament turnover in lamellipodia. Science.2002; 295: 1083-6.

[59]. Wojciak-Stothard, B., and Ridley, A. J. Shear stress-induced endothelial cell polarization is mediated by Rho and Rac but not Cdc42 or PI 3-kinases. J Cell Biol.2003; 161:429-39.

[60]. Yao, Z., Lafage-Proust, M. H., Plouet, J., Bloomfield, S., Alexandre, C., and Vico, L. Increase of both angiogenesis and bone mass in response to exercise depends on VEGF. J Bone Miner Res. 2004; 19:1471-80.

[61]. Zhang, L., Conejo-Garcia, J. R., Yang, N., Huang, W., Mohamed-Hadley, A., Yao, W., Benencia, F., and Coukos, G. Different effects of glucose starvation on expression and stability of VEGF mRNA isoforms in murine ovarian cancer cells. Biochem Biophys Res Commun.2002; 292:860-8. 


\section{Tables}

Table 1

DNA sequences of sense and anti-sense primers

\begin{tabular}{|c|c|c|c|c|c|}
\hline Target & Species & Primers & $\operatorname{Tm}\left(^{\circ} \mathrm{C}\right.$ & Product size $(\mathrm{pb})$ & Source \\
\hline \multirow[t]{2}{*}{ Hif-1a } & \multirow[t]{2}{*}{ Rat } & forward 5'-TCAAGTCAGCAACGTGGAAG-3' & 60 & \multirow[t]{2}{*}{198} & \multirow[t]{2}{*}{ NM_024359 } \\
\hline & & reverse 5'-TATCGAGGCTGTGTCGAGTG-3' & 62 & & \\
\hline \multirow[t]{2}{*}{ VEGF-A } & \multirow[t]{2}{*}{ Rat } & forward 5'-TTTACTGCTGTACCTCCACC-3' & 60 & \multirow[t]{2}{*}{316} & \multirow[t]{2}{*}{ NM_031836 } \\
\hline & & reverse 5'-АTСTCTCСTATGTGCTGGCT-3' & 60 & & \\
\hline \multirow[t]{2}{*}{ VEGF-188 } & \multirow[t]{2}{*}{ Rat } & forward 5'-CGAGGAAAGGGAAAGGGTCA -3' & 62 & \multirow[t]{2}{*}{178} & \multirow[t]{2}{*}{ NM_031836 } \\
\hline & & reverse 5'-TTAACTCAAGCTGCCTCGCC -3' & 62 & & \\
\hline \multirow[t]{2}{*}{ VEGF-120 } & \multirow[t]{2}{*}{ Rat } & forward 5'-TTTACTGCTGTACCTCCACC-3' & 60 & \multirow[t]{2}{*}{269} & \multirow[t]{2}{*}{ NM_031836 } \\
\hline & & reverse 5'-CAATGATGAA TGAACAAGGC-3' & 56 & & \\
\hline \multirow[t]{2}{*}{ Cyclophilin } & \multirow[t]{2}{*}{ Rat } & forward 5'-AGCACTGGGGAGAAAGGATT-3' & 60 & \multirow[t]{2}{*}{281} & \multirow[t]{2}{*}{ M19533 } \\
\hline & & reverse 5'-TTCACCTTCCCAAAGACCAC-3' & 60 & & \\
\hline \multirow[t]{2}{*}{ VEGF-206 } & \multirow[t]{2}{*}{ Human } & forward 5'- GGCCCCCATCCCTGTGGGCC -3' & 72 & \multirow[t]{2}{*}{173} & \multirow[t]{2}{*}{ NM_003376 } \\
\hline & & reverse 5'- CTCCTGCCCGGCTCACCGCC -3' & 72 & & \\
\hline \multirow[t]{2}{*}{ VEGF-189 } & \multirow[t]{2}{*}{ Human } & forward 5'-CCTGGAGCGTTCCCTGTGGG-3' & 68 & \multirow[t]{2}{*}{176} & \multirow[t]{2}{*}{ NM_003376 } \\
\hline & & reverse 5'-CTCCTGCCCGGCTCACCGCC-3' & 72 & & \\
\hline \multirow[t]{2}{*}{ VEGF-165 } & \multirow[t]{2}{*}{ Human } & forward 5'-CAAGAAAATCCCTGTGGGCC-3' & 57 & \multirow[t]{2}{*}{175} & \multirow[t]{2}{*}{ NM_003376 } \\
\hline & & reverse 5'-CTCCTGCCCGGCTCACCGCC-3' & 72 & & \\
\hline \multirow[t]{2}{*}{ VEGF-145 } & \multirow[t]{2}{*}{ Human } & forward 5'-GGACATCTTCCAGGAGTACC-3' & 62 & \multirow[t]{2}{*}{328} & NM_003376 \\
\hline & & reverse 5'-CTTGTCACATACGCTCCAGG-3' & 62 & & \\
\hline VEGF-121 & Human & forward 5'-GGACATCTTCCAGGAGTACC-3' & 62 & 258 & NM_003376 \\
\hline & & reverse 5'-GGCTTGTCACATTTTTCTTG-3' & 62 & & \\
\hline Cyclophilin & Human & forward 5'-AGCTGTTTGCAGACAAAGTT-3' & 56 & 322 & AF022115 \\
\hline & & reverse 5'-CCAAAGACCACATGCTTGCC-3' & 62 & & \\
\hline
\end{tabular}




\section{Figure captions}

Figure 1: (A) Design of experimental protocol: design of 4 mechanical stretches varying in time and frequency (excitation time is not at scale). For a constant number of cycles applying a $1 \%$ deformation (square), applied frequencies ranging from $0.05 \mathrm{~Hz}$ to $5 \mathrm{~Hz}$ with a respective decreasing time of $150 \mathrm{~min}$ to $1.5 \mathrm{~min}$. Analysis were performed $12 \mathrm{~h}$ post stretch (if not stated). (B) Diagram of the VEGF isoforms and location of primers.

Figure 2: ( $A$ and $B$ ) Effects of mechanical stretches frequency on Hif- $1 \alpha$ and VEGF-A gene expressions in Ros17/2.8 cells. (A) Effect of mechanical stretches on Hif- $1 \alpha$ gene expression 6 hours post stretch (B) Effect of mechanical stretches on VEGF-A gene expression 12 hours post stretch. Expressions were normalized on the basis of cyclophilin expression and the data were expressed as percentage of the control value (C, 100\%). Results were obtained from 4 independent experiments $(n=8) . * p<0.01$ (Scheffe test) vs. "C". (C and D) Production or immobilisation of VEGF $12 \mathrm{H}$ post stretch in Ros17/2.8. (C) Soluble VEGF; VEGF protein amount determined by specific ELISA in supernatant of culture for mechanical stretch varying in frequency. (D) VEGF immobilisation, VEGF protein amount determined by specific ELISA in cell and matrix lysates. Values are expressed as percentage of control production (" $C$ ", 100\%). Experiments were conducted at least three times on 6 samples in each group. * $\mathrm{p}<0.01$ vs " $\mathrm{C}$ ". (Scheffe test).

Figure 3: VEGF specific isoforms expressions according to mechanical stretch frequency. (A) vegf isoforms expression (120 and 188) were quantified on Ros17/2.8 osteoblast at $0.05 \mathrm{~Hz}$ and $5 \mathrm{~Hz}$. (B) vegf isoforms expression (121, 145, 165, 189 and 206) were quantified on primary human osteoblast at $0.05 \mathrm{~Hz}$ and $5 \mathrm{~Hz}$. Soluble vegf isoforms were indicated with grey bars and matrix-bound vegf isoforms using black bars. Expressions were normalized on the basis of cyclophilin expression and the data were expressed as percentage of the control value (C, 100\%). $n=4, * p<0.01$ (Scheffe test) vs. "C". (C-D) Production or immobilisation of VEGF 12 hours post stretch in human primary osteoblasts. (C) Soluble VEGF; VEGF protein amount determined by specific ELISA in supernatant of culture for mechanical stretch at 0.05 and $5 \mathrm{~Hz}$. Values are expressed as percentage of control production ("C", 100\%). (D) VEGF immobilisation, VEGF protein amount determined by specific ELISA in cell and matrix lysates. Experiments were conducted at least three times on 6 samples in each group. $* p<0.01$ vs C. (Scheffe test). (E) Effect of mechanical stretches on Hif- $1 \alpha$ protein production 12 hours poststretch on primary human osteoblasts. Data were expressed in $\mathrm{ng} / \mathrm{ml}$. Results were obtained from 2 independent experiments $(n=6)$. ${ }^{*} p<0.01$ (Scheffe test) vs. " $C$ ". (F) 12 hours post stretches $(0.05$ and $5 \mathrm{~Hz}$ ), primary human osteoblast were removed from silicone membrane by using freezing/unfreezing cycles and double staining of VEGF and Hoechst was performed to determine the presence of matrix-bound VEGF as well as absence of cells. Scale bar: $40 \mu \mathrm{m}$. "C": static control.

Figure 4: Effect of different mechanical stretch regimens on actin stress fiber formation in Ros17/2.8 cells. (A) Cells cultured onto flexible type I collagen-coated membrane were fixed and stained for $\mathrm{f}$-actin (Rhodamine-phalloidin) $12 \mathrm{H}$ after stretches ranging from 0.05 to $5 \mathrm{~Hz}$ or static condition " $\mathrm{C}$ ". Scale bar $=20 \mu \mathrm{m}$. Stretch regimens with highest frequencies presented numerous $f$-actin stress fibers. (B) Quantification of fiber spacing by way of autocorrelation demonstrated that high frequency regimens significantly induce stress fiber formation. Typical ROI analysed were indicated by blank squares and respective autocorrelation images were inserted in bottom left corner, a diffuse pattern was indicative of absence of fibers $(0.25 \mathrm{~Hz})$ and a striated pattern indicative of presence of fibers $(2.5 \mathrm{~Hz})$. See details in methods section. $\mathrm{n}=30, * \mathrm{p}<0.01$ vs. "C" (Scheffe test). 
Figure 5: Effect of actin polymerisation manipulation in Ros 17/2.8 on VEGF isoform expression and release or immobilisation into matrix. (A) Visualisation of stress fibers by $\mathrm{f}$-actin staining using phalloidin. Cells were treated either with Jasplakinolide "Jasp." or Latrunculin A "Lat.A" or untreated "C". (B) vegf isoform expression 188 (matrix-bound) was assessed on Ros17/2.8 after Lat. A and Jasp. treatments (black bars) as compared to untreated cells (white bars). (C) vegf isoform expression 120 (soluble) was assessed on Ros17/2.8 after Lat.A and Jasp. treatments (black bars) as compared to untreated cells (white bars). Expressions were normalized on the basis of cyclophilin expression and the data were expressed as percentage of the control value $(C, 100 \%) . n=4, * p<0.01$ (Scheffe test) vs. "C". VEGF protein amount were quantified in supernatant (SN) and cell/matrix lysates (LYS) after Jasp. treatment (D) or Lat.A treatment (E). Jasplakinolide treatment increased significantly upregulation of matrix-bound vegf188 isoform and immobilisation of VEGF indicating that actin polymerisation is necessary for VEGF immobilisation. LatrunculinA had no effect on VEGF release or immobilisation. $n=8$, * $p<0.01$ (Scheffe test) vs. "C".

Figure 6: Effect of actin depolymerisation in Ros17/2.8 on mechanically induced-VEGF release or immobilisation. (A) Visualisation of stress fibers by f-actin staining using phalloidin Cells were treated with LatrunculinA "Lat. A" or untreated "C" prior to mechanical stretch episode at 0,05 "Lat.A+0.05Hz" and $5 \mathrm{~Hz}$ "Lat.A+5Hz". (B) vegf isoforms expression (120 and 188) were quantified on Ros $17 / 2.8$ osteoblast at $0.05 \mathrm{~Hz}$ and $5 \mathrm{~Hz}$ following a pre-treatment with Lat. A. grey bars corresponded to vegf 120 isoform and black bars to vegf188 isoform. Expressions were normalized on the basis of cyclophilin expression and the data were expressed as percentage of the control value (C, 100\%). $n=4, * p<0.01$ (Scheffe test) vs. "C". VEGF protein amount was quantified in supernatant (C) and cell/matrix lysates (D). LatA. treatment did not block the release of VEGF at $0,05 \mathrm{~Hz}$ but completely abolished VEGF immobilisation. $\mathrm{n}=8, * \mathrm{p}<0.01$ (Scheffe test) vs. C. 


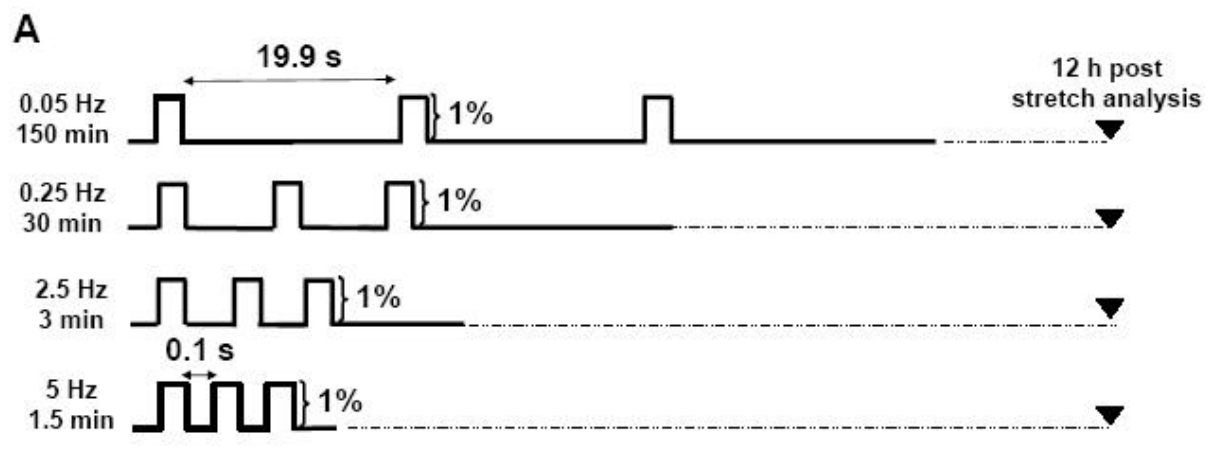

B

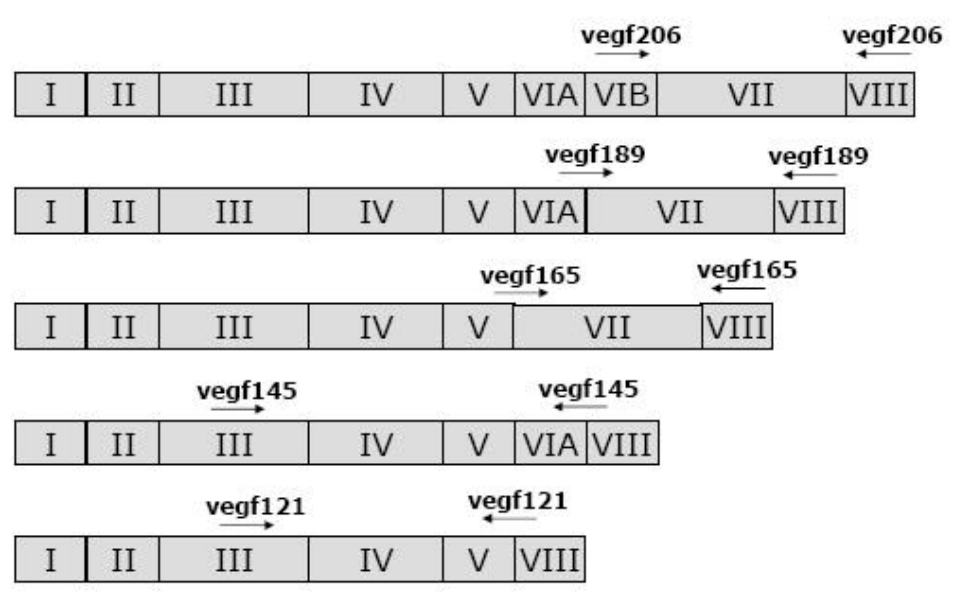

Faure et al., Fig. 1 


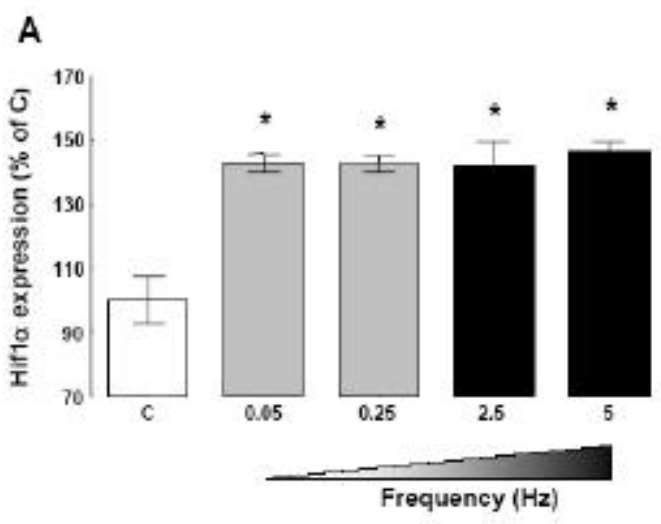

B

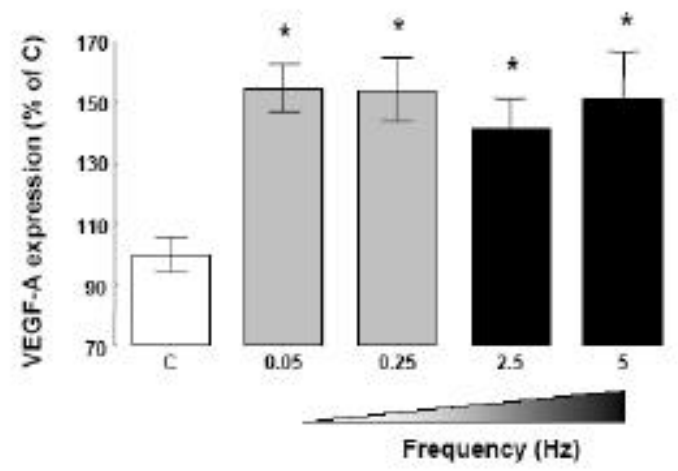

c

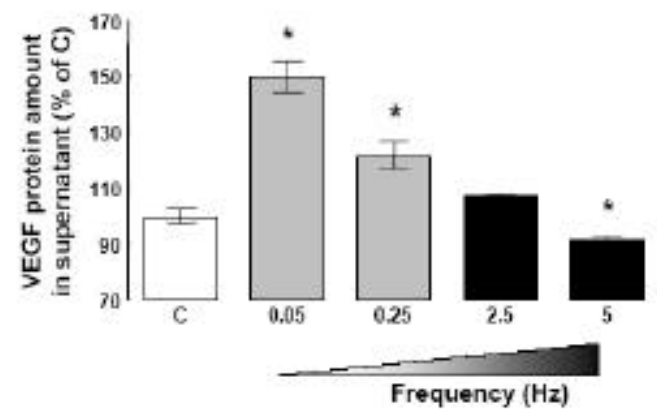

D

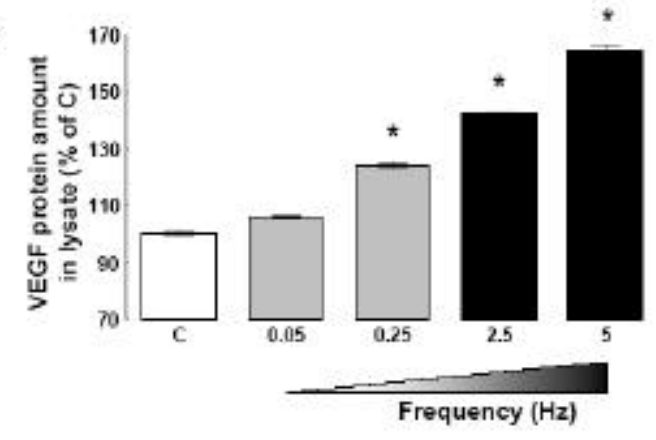

Faure et al., Fig. 2 

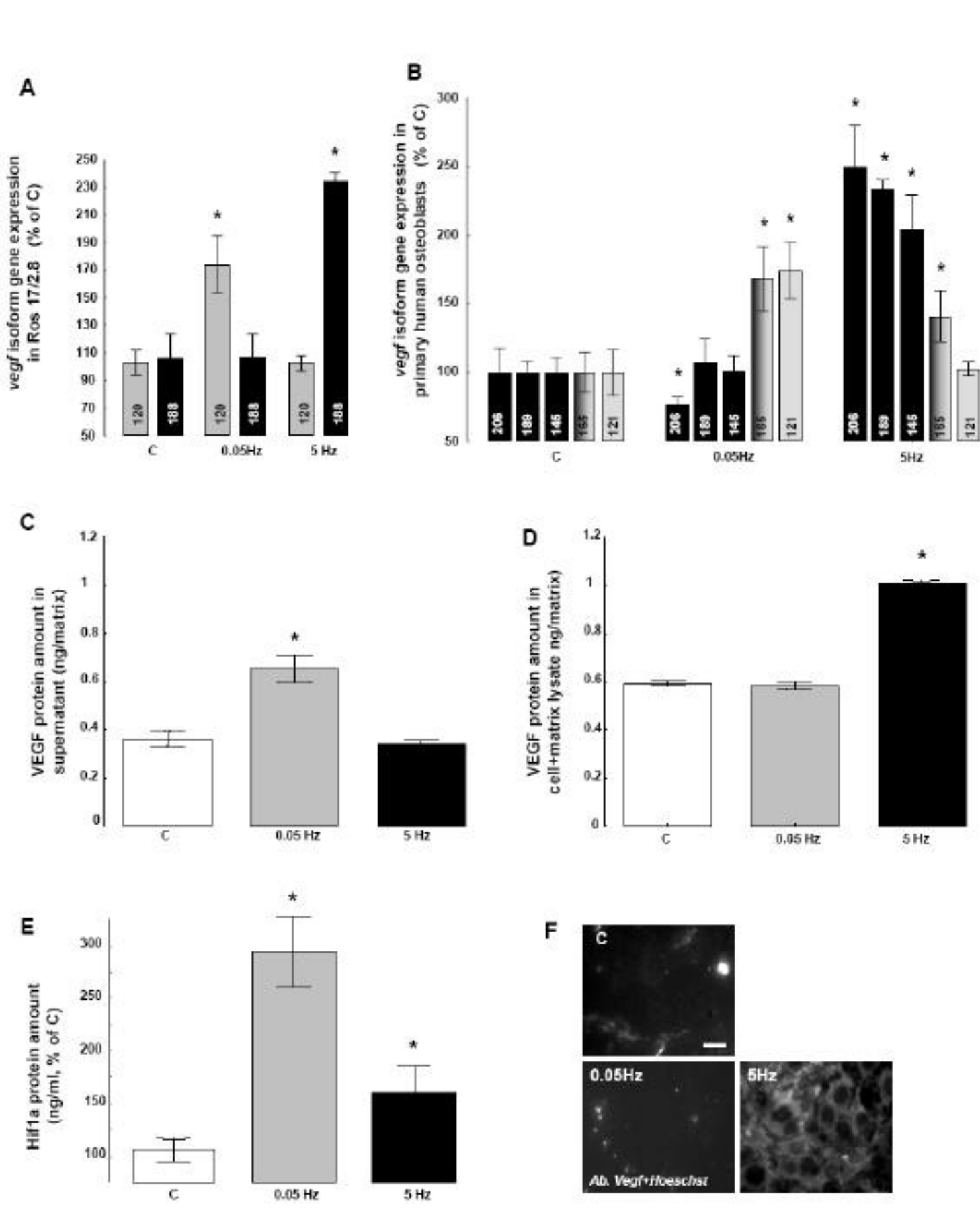

Faure et al., Fig. 3 

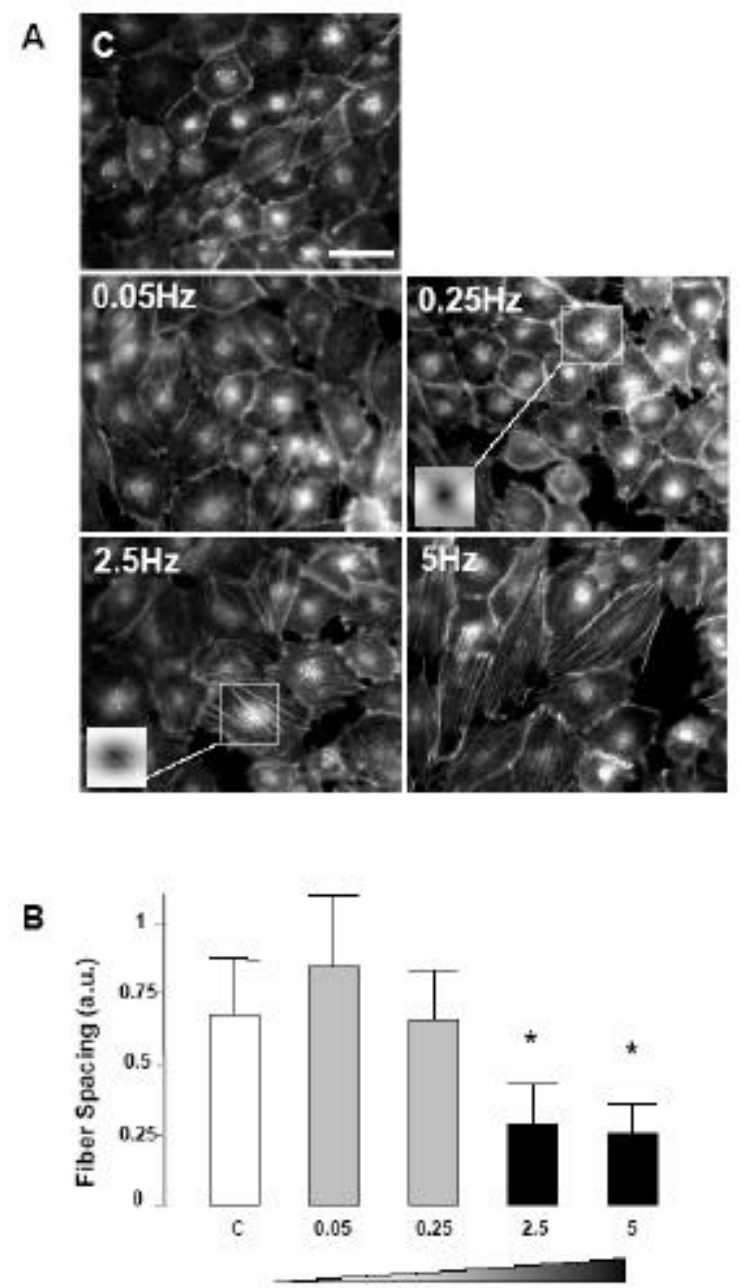

Frequency $(\mathrm{Hz})$

Faure et al., Fig. 4 

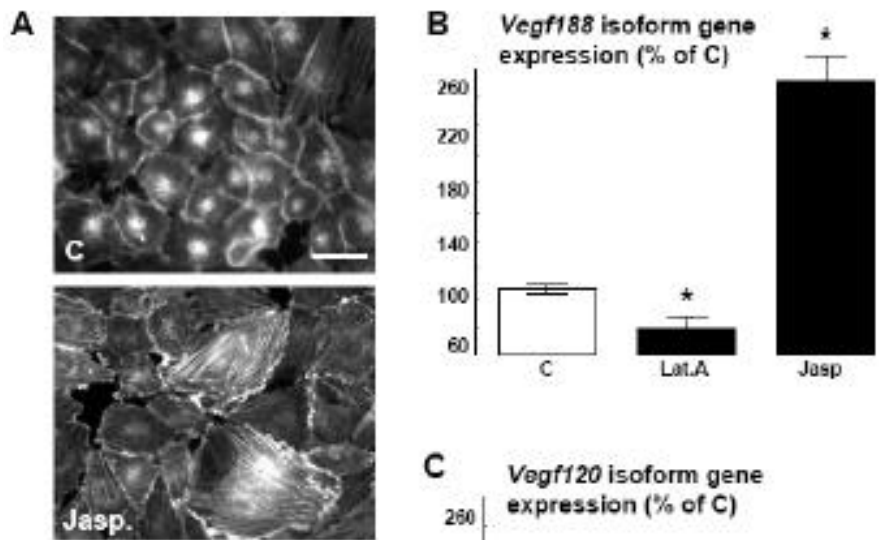

D VEGF protein amount ( $\%$ of C)

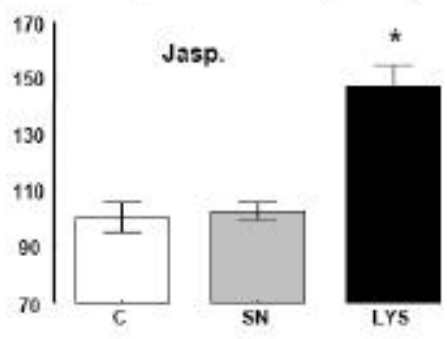

C Vegf120 isoform gene

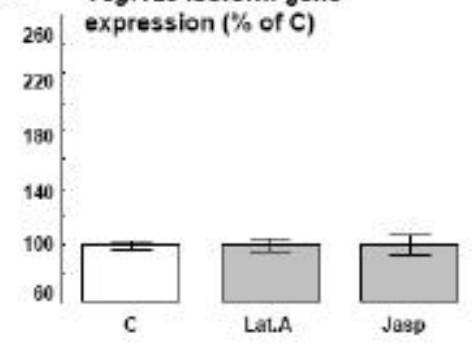

E

VEGF protein amount ( $\%$ of C)
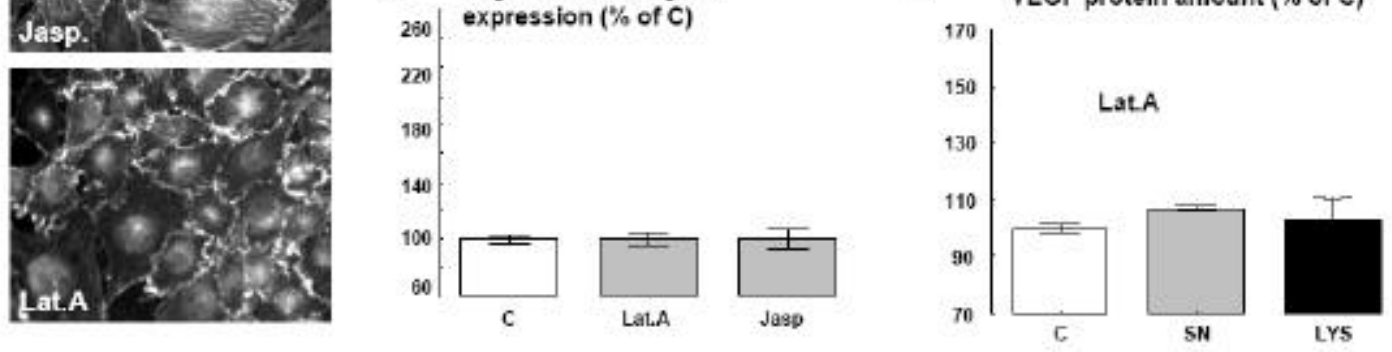

Faure et al., Fig. 5 

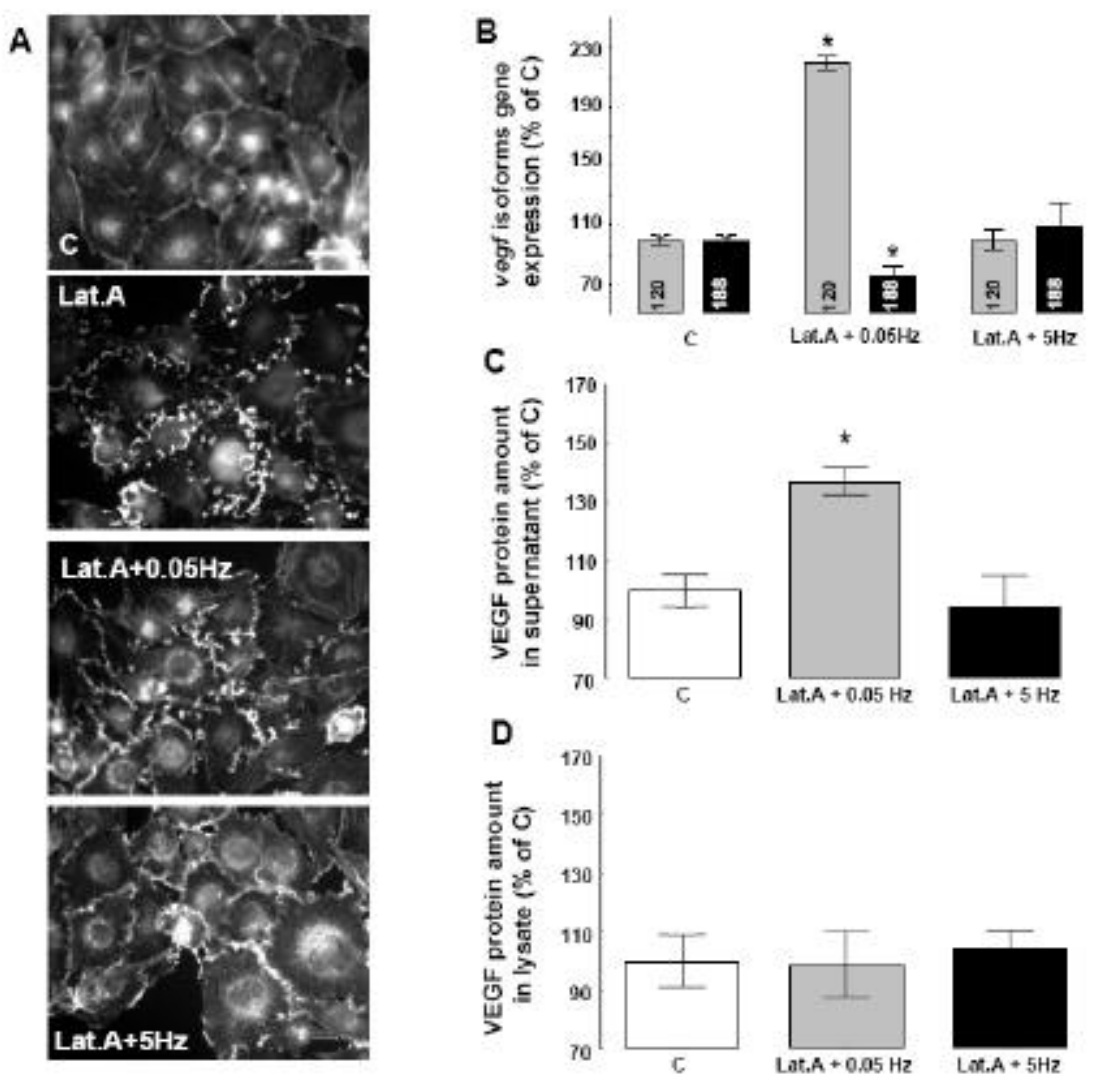

Faure et al., Fig. 6 